IRSH 56 (20I I), Special Issue, pp. 21 7-243 doi:I0.1017/S00208590 I I000502

(C) 20I I Internationaal Instituut voor Sociale Geschiedenis

\title{
Japan in the Seventeenth Century: Labour Relations and Work Ethics*
}

\author{
REGINE Mathias \\ Faculty of East Asian Studies, Rubr-Universität Bochum \\ E-mail: regine.mathias@rub.de
}

\begin{abstract}
SUMMARY: In Japan, the transformation of labour relations from medieval forms of serfdom, lifelong service, and corvée labour to short-term contracts and wage labour was already under way by the seventeenth century. In the second half of the seventeenth century short-term employment based on contracts became common. Indentured labour gradually changed into wage labour. Government policies included enabling greater mobility for the workers, while also trying to set limits to migration flow to the cities. Some Confucian scholars welcomed this new form of labour relations; others condemned them. The few sources about the work ethics of waged workers imply mockery about their loose morals and work attitudes, but also complaints about workloads and exploitation.
\end{abstract}

\section{INTRODUCTION}

Around I 500 , Japan's elite was in the midst of prolonged warfare, the supremacy of the central government was fast declining, while many territorial lords (daimyo) were assuming unprecedented power. The whole country was in a process of political decentralization, which was accompanied by social upheaval on various levels. During this development many of the traditional structures, such as the landed estates, which had been the primary production units in medieval Japan, were finally destroyed, and the territorial lords gradually gained direct control of the people in their domains.

Sources on the life and work of the common people are scarce and scattered, and little is known about the work situation and the work ethics of those who performed manual labour. Confucianism or neo-Confucianism, which was to become the main ideology in the seventeenth century, was known, but not widespread. If there was any kind of work ethic, it would

* In this article east Asian names are given in the sequence family name - personal name.

Exceptions are made in cases where authors have adopted Western personal names. 
have been rooted in Buddhism. Although artisans with special skills, who could probably be regarded as semi-free, formed small guilds $(z a)$, and sought employment by local lords and temples in some places, the prevalent forms of labour were serfdom, lifelong service (semi-free indentured service), and corvée labour.

In the last three decades of the sixteenth century, efforts began to unify the country under a new central government. After a decisive battle in I 600 , a new regime under the control of the supreme military governors (shogun), the Tokugawa family, was set up and lasted for more than 250 years until the Meiji Restoration in I868. Many historians regard the so-called Tokugawa (or Edo) period as comparable with the early modern period in European history. In the evolving political and administrative system, the central power of the shogunate coexisted with more than 200 feudal domains, whose lords were legally vassals of the shogun, but acted as rather independent rulers in their domains. To maintain this delicate balance of power, the Tokugawa shoguns established an administrative framework based on policies already introduced by their predecessors, by which they tried to control their vassals firmly and stabilize their own rule.

Among the measures to achieve that goal, two are of special importance for changes in labour relations: first, a strategy of urbanizing the warrior class by separating warriors and peasants and forcing the former to reside in the emerging castle towns; and second, a system of alternate attendance (sankin kōtai), by which the feudal lords were to live alternately in Edo and in their domains, building and maintaining castles and residences in both places. The result was an unprecedented boom in urban construction starting in the 1580 s and extending far into the seventeenth century. Castle towns had to accommodate thousands of warriors and their entourages as well as artisans and merchants who provided the material basis for their living. This created a huge demand not only for goods and services, but also for manual labourers, which forced the shogunate to overlook the traditional ban on peasant migration and reluctantly concede the development of new forms of service and labour, especially in the cities, but also in some rural areas.

In the I 580 s and I 590 S Toyotomi Hideyoshi had explicitly forbidden the hiring of day labourers. In his "Edict on Change of Status" of I 59 I, which was part of his efforts to separate warriors from peasants, disarm the peasantry, and stabilize agricultural production after long years of war, Hideyoshi demanded that "if any farmer abandons his wet and dry fields and engages in trade or offers himself for hire for wages, not only is he to

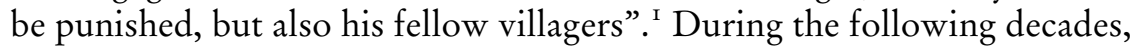


however, this attitude on the part of the central administration was softened and adapted to the changing situation.

Studies on this transformation process which focus on work, the emergence of an urban workforce, ensuing changes in labour relations in rural and urban areas, or the spread of a work ethic and its actual impact on the thought and behaviour of the workforce are still few in number. There are, however, groundbreaking works by Thomas C. Smith, Saitō Osamu, Herman Ooms, Gary Leupp, Mary Louise Nagata, and others, whose findings have greatly helped in formulating the following outline of the transformation of labour relations in rural and urban areas, and the possible impacts of a work ethic.

\section{THE SITUATION IN RURAL AREAS}

Despite the sudden emergence and growth of castle towns and other urban centres at the turn of the sixteenth century, the majority of Japanese people continued to live and produce in the countryside throughout the early modern period (I600-I 868). While we have a rich stock of sources concerning the seventeenth to the nineteenth centuries, the economic historian Hayami Akira has pointed out that "since there are few literary source materials in Japan much before I600 that tell us about social conditions, such as how peasants lived and produced, no real contrast can be made between pre-I600 and post-I600 socio-economic conditions through primary historical sources". ${ }^{2}$ Therefore the following remarks on traditional forms of labour in agriculture will focus mostly on the period after 1600 .

The complete disintegration of the landed estates in the sixteenth century was accompanied by the expanding autonomy of newly emerging village communities on the one hand, and by the efforts of the daimyo to gain control over their territories and people on the other. In this process the daimyo developed a great variety of systems and regulations to cope with landholdings, tax collection, and recruitment for military service, but the unification process which started in the late sixteenth century established new principles of land possession. A nationwide cadastral survey (taiko-kenchi) registered plots of land in the names of peasants, who could henceforth claim possession rights for these parcels, while proprietorship remained with the territorial lord. Even though the cadastral survey laid

2. Hayami Akira, "A Great Transformation: Social and Economic Change in Sixteenth and Seventeenth Century Japan”, in Erich Pauer (ed.), Silkworms, Oil and Chips (Proceedings of the Economics and Economic History Section of the Fourth International Conference on Japanese Studies, Paris, September 1985), Bonner Zeitschrift für Japanologie, VIII (Bonn, I986), pp. 3-13, 5; repr. in Hayami Akira, Collected Papers of Akira Hayami: Population, Family and Society in Pre-Modern Japan [The Collected Papers of Twentieth-Century Japanese Writers on Japan], IV (Folkestone, 2009), pp. 42-5 I, 43. 
the ground for the emergence of a peasant economy, based on labourintensive, small-scale family farming, it did not create one single class of small, independent cultivators. Instead, the social structure of the village communities comprised several strata, from wealthy and influential farmers to smaller independent cultivators, cultivators dependent on landowning patrons, landless peasants, and serfs. ${ }^{3}$

\section{RECIPROCAL LABOUR IN THE COUNTRYSIDE}

Although large landholdings did not completely disappear, the majority of the landowning peasants (bonbyakusho) were registered for smaller plots of land of one $c h o^{-}$(c. I hectare) or less. It seems that often the plots became so small that they could no longer support even the nuclear family. According to a treatise on farming from I685, the Honen zeisho [Writings on Taxes in Years of Abundance], "everywhere fields are divided and re-divided, until finally holdings of seven, five, and even one tan [c.I,००० square metres] or less appear. The holders of such small farms put their children out in the service of others." 4 This statement is supported by other sources. Smith mentions the example of a group of sixty-nine servants in one village in 1678 , of whom "all but one came from families with fewer than five koku of arable and forty-one [...] from families with fewer than three koku",' which means that the income in rice did not suffice to feed more than two to four persons in the household. ${ }^{6}$

Service in the countryside could take on several forms, which can be roughly divided into hereditary servants (fudai) and indentured servants bound for exceedingly long terms (genin), but the lines between these categories are often blurred and the terms are used interchangeably. Besides those two categories, which could be labelled "agricultural servants", Smith distinguishes a third group, namely serfs, who would farm small plots of land allotted to them by the landholder, to whom they owed labour services in return. Smith calls them nago, but there are many other local names (bikan for instance) for these dependent cultivators of land.

Although it is extremely difficult to assess the numbers of genin and nago, Smith used scattered population registers to estimate that genin accounted for about Io per cent of the peasant population in the seventeenth

3. Wakita Osamu, "The Social and Economic Consequences of Unification", in John Whitney Hall et al. (eds), The Cambridge History of Japan, IV: Early Modern Japan (Cambridge, I99I), pp. 96-I 27, I05-I IO.

4. Thomas C. Smith, The Agrarian Origins of Modern Japan (Stanford, CA, I959), p. I2.

5. Ibid.

6. One koku is equivalent to I 80 litres of rice, which is sufficient to feed one person for one year. But since peasants usually had to pay taxes in rice, the amount at their disposal was much less than the number of koku registered for their fields. 
century, whereas the proportion of nago varied greatly. The results of a census in Buzen (northern Kyūshū) carried out between I68 I and I684 show that 36 to 60 per cent of the village population were nago. In another example of I 4 villages in Echigo (now Niigata prefecture) the nago made up between 4 and 70 per cent of the peasant population.?

Hereditary servants and long-time indentured servants, whose term ranged from ten years to a whole lifetime, lived with their master and worked for him in the fields as well as in the home or in the household business. They were considered part of the family. The master was responsible for their food and clothing, and, in the case of young servants, also for their upbringing. Such servants were usually registered in the population registers as family members, but with a notation that marked them as servants, not kin. They often seem to have been treated quite similarly to the younger children of the master's family.

According to Smith, hereditary servants could marry and form their own families, who would often move into a separate dwelling near the main house. Although servants or their children could be sold or given as servants to daughters of the master upon marriage, many of them seem to have lived with the master's family for generations. ${ }^{8}$

Hereditary servants were either offspring of such servants or acquired by purchase or as a "gift" from poor families. Selling surplus members of poor families as either hereditary or long-term servants to better-off families in need of labour was obviously very common. Smith cites the journal of a peasant family in the eighteenth century, in which statements on crop failures are often accompanied by reports of local families selling members as hereditary servants. He also gives the example of a single county in northern Honshū, where during the 7 years from I622 to I629 more than 6,000 people were sold as hereditary servants. ${ }^{9}$

That selling people into service was a very widespread phenomenon is also shown by the frequency of laws dealing with this topic in the seventeenth century. Although trade in human beings (jinshin baibai) had been periodically banned before, and although the daimyo Toyotomi Hideyoshi, the second of the three "great unifiers" of the country, had explicitly outlawed trade in persons (bito no baibai) in I 587 , the selling of children by families in economic distress seems not to have been affected by these laws. Between 1616 and 1716 the Tokugawa shogunate issued numerous laws banning the sale of persons, while at the same time limiting service terms to three years in the early laws and ten years in the later ones. ${ }^{10}$

7. Smith, Agrarian Origins of Modern Japan, pp. 8-10.

8. Ibid., pp. I $3^{-1} 4$.

9. Ibid., p. Is.

Io. Gary P. Leupp, Servants, Shophands and Laborers in the Cities of Tokugawa Japan (Princeton, NJ, I992), p. 20. 


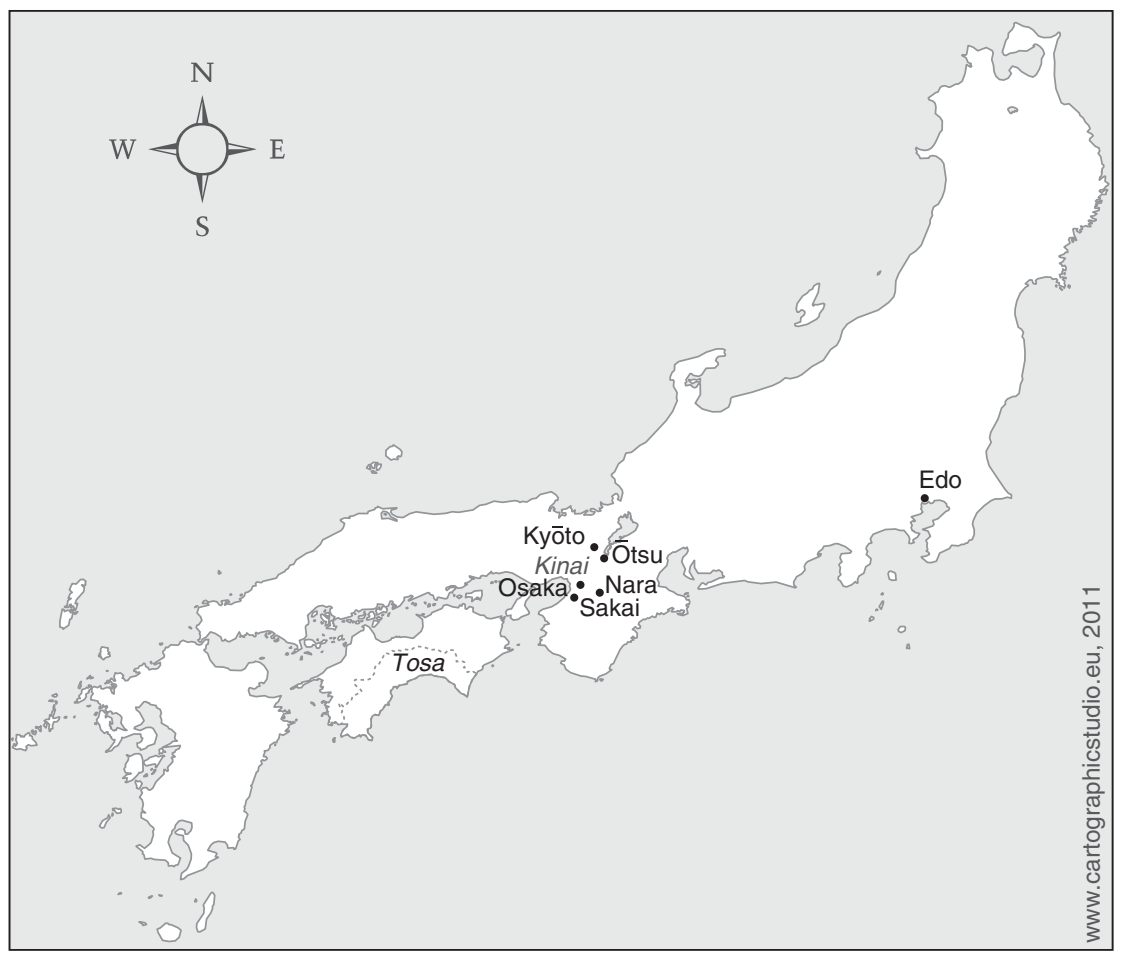

Figure I. Map of Japan.

These laws were soon integrated into village regulations, as two examples of rules for the five-household neighbourhood units from 1640 and 1662 show. Both contain clauses prohibiting traffic in humans and limiting the terms of indentured servants. ${ }^{\text {I }}$ Little is known about the implementation of these rules in the villages, but as stories of children sold into long-term or lifetime service by their families in times of distress continue to be told throughout the early modern period, this custom seems to have prevailed until far into the nineteenth century.

The perseverance of long-term or lifetime service is also apparent in the development of laws. Whereas laws in the first half of the seventeenth century tended to ban indefinite or lifetime service completely, later ones (I675, I698) stipulated that service could be extended (unlimitedly) by mutual consent (sotai shidai). The rationale behind this apparent retrogression is not clear, but one reason could have been the attempt to respond to a certain demand and to stabilize labour relations during a period of great change. As will be shown 
in the second part of this article, short-service terms of six months or one year had already become quite common at the end of the seventeenth century in many areas, especially in the urban labour force, and therefore long-term service did not regain its former importance. It seems to have prevailed in some rural areas and in the realm of skilled labour in crafts and trade, while casual labour and unskilled work in urban areas tended towards a market-like relationship based on wages.

Another part of agricultural labour was provided by the nago, who cultivated land but were completely dependent on the landholder for housing, tools, animals, and other resources. In return they owed the landholder labour services upward of 30 or 40 days per year, which could be extended in some areas in certain years to as much as 200 days. ${ }^{\mathrm{I}}$

\section{FROM SUBSISTENCE FARMING TO COMMERCIALIZED AGRICULTURE AND SIDE WORK}

With the expansion of commerce and industry in the late seventeenth and throughout the eighteenth century, some economically advanced areas saw a transformation of agricultural labour, which gradually spread to other parts of the country. These developments began to evolve first in Kyōto and the Kinai area, i.e. the provinces surrounding the cities of Kyōto, Nara, Ōsaka, and Ōtsu, as well as in the port town of Sakai (Figure I).

Kyōto had been the hub of commercial activities for a long time. In the fourteenth century peasants in nearby villages apparently began to produce goods such as noodles, lamp oil, vinegar, and malt to sell in the cities. Some of these peasants even formed guilds (inaka-za) under the protection of powerful patrons, modelled after similar organizations of artisans and merchants in Kyōto and other cities. ${ }^{13}$ At the same time, coins imported from China since the end of the twelfth century circulated not only in the central Kinai area but also in villages and markets along the great highways and became an additional incentive for peasants to produce for the market. In the fourteenth and fifteenth centuries the number of cities and towns as well as their population increased. Much of this growth was based on the growth of commerce, which expanded to regional markets. So, in the mid-sixteenth century, the Kinai area was economically already far advanced, and commercial transactions at markets and annual taxes were based mostly on coins. There were also other "scattered islands of commercial farming in Japan". ${ }^{4}$

I 2. Smith, Agrarian Origins of Modern Japan, p. 26.

I3. Nagahara Keiji, "The Medieval Peasant", in Kozo Yamamura (ed.), The Cambridge History of Japan, III: Medieval Japan (Cambridge, I990), pp. 30I-343, 327-328; Wakita Haruko, "Towards a Wider Perspective on Medieval Commerce", Journal of Japanese Studies, I (1975), pp. 32 I-345, 336-337.

14. Smith, Agrarian Origins of Modern Japan, p. 67. 
The reforms during the unification process greatly changed the framework for agricultural and commercial activities. New policies of registering land in the name of the cultivators since the I 580 , and the "return of the rice-using economy" through the introduction of the kokudaka system, in which land was measured in terms of rice output (kokudaka), and rice became again the main basis of taxation, put an end to the medieval economy. ${ }^{15}$ However, these changes did not prevent the further spread of commerce and its growing importance for the economy as a whole, although they might have contributed to form its special structure, which differs from similar developments in Europe.

From the late I630s the Tokugawa shogunate began to cast its own coins in large quantities, and the almost monetary role of rice was complemented by a tri-metallic currency system of gold, silver, and copper monies. Over time money became the common medium of exchange in the cities, but also at numerous rural markets, which sprang up everywhere. A list of commodities regularly sold at a village market in the Aizu domain (now Fukushima prefecture) in 1665 included cloth, harnesses, cotton, paper, rice, soya beans, firewood, hoes, hoe handles, sickle handles, winnowing baskets, looms, tobacco, grain, vegetables, mortars, straw hats, and straw matting. ${ }^{16}$ The wide range of goods sold and purchased at that market shows that, already in the second half of the seventeenth century villagers relied on these markets for buying, but also for selling, many essentials.

With the spread of commerce and industry in the seventeenth century, cotton, one of the main cash crops, became prevalent in many areas, while others such as indigo, tobacco, and safflowers were produced as regional specialities. The production of raw cotton provided additional work for peasants and also entailed the emergence of a cottage industry gradually producing cotton thread and cloth far beyond the needs of the peasant families.

The growing importance of the domestic production of raw silk and silk cloth, which came to be substituted for expensive imports from China from the beginning of the eighteenth century, also created new opportunities for secondary employment for peasant families. Some other traditional side activities of peasants, such as hemp production, bleaching, and weaving, expanded considerably after the late seventeenth century. ${ }^{17}$

The commercialization of agriculture and the growth of rural industries as well as the growing demand for labour in the urban centres influenced the composition of the rural labour force in many parts of the country.

I s. Concerning the background to this development see Kozo Yamamura, "From Coins to Rice: Hypotheses on the Kandaka and Kokudaka Systems", Journal of Japanese Studies, I4 (1988), pp. 34I-367; Wakita Osamu, "The Kokudaka System: A Device for Unification”, Journal of Japanese Studies, I (1975), pp. 297-320.

16. Smith, Agrarian Origins of Modern Japan, p. 73.

17. Ibid., p. 77. 
Smith relates the gradual disappearance of hereditary servants in economically advanced regions and their replacement by servants hired for a fixed period and payment (bokonin) to the spread of cash crops and other forms of commercialization in rural areas. Another phenomenon he mentions was the increase in tenant cultivation, which spread from the Kinai area, where it was already quite common in the seventeenth century, to other economically advanced regions during the eighteenth century. In these regions, nago often seem to have become tenants or to have been replaced by tenants during this gradual shift, while there were some rare cases in which nago purchased their land and personal freedom from their master. ${ }^{18}$

Although many of the changes starting in the mid-seventeenth century seem to suggest that patterns of rural industrialization in Japan were similar to those in western Europe, in his comparative studies on protoindustrialization Saitō Osamu stresses the structural differences, which also influenced the form of labour within that framework.

In Japan the development of rural industries had little impact on demography and the internal structure of the traditional peasant family economy. As the population density was three times higher than that of Flanders at the beginning of the eighteenth century and farm units were extremely small, the development of rural industries generally did not result in further fragmentation of the farms. Instead, farmers increased their land productivity by using new technologies, fertilizer, and improved irrigation as well as labour-intensive cultivation methods. At the same time, they took advantage of newly emerging opportunities for side work in crafts, commerce, and transport to supplement their incomes.

The strong intertwining of agriculture and rural industry, which Saitō regards as characteristic for most parts of Japan throughout the early modern period, makes it difficult to clearly differentiate between labour for subsistence and labour for a market. Both were usually conducted in the same household, though not necessarily by the same persons. The workforce available to the farm household had to be allotted to farming (food crops) and rural industries (including cash crops), and this was done, as Saitō points out, often along gender lines. ${ }^{19}$

\section{THE ROLE OF WOMEN}

Especially in textile production the division of labour between the sexes within peasant households was relatively clear. In contrast to traditional side work such as paper manufacturing, which was done by the whole family in the slack season, employment in textile production was limited

I8. Ibid., pp. І09-І 10, I3 I-I 37 .

19. Saitō Osamu, "Population and the Peasant Family Economy in Proto-Industrial Japan", Journal of Family History, 8 (1983), pp. 30-54, 40-4I. 
mostly to the women in the household. The assignment of the work of spinning and weaving to female members of a family can be traced back far into Japanese history and can also be found in China and other parts of the world. Shortly before the spread of rural industrialization, an edict, said to have been issued by the shogunate in I649 and addressing the peasants directly, stated that "Both husband and wife should work for a living: the husband in the fields, the wife at the loom and preparing the evening meals". ${ }^{\circ}$ In a well-known and widely read treatise on proper behaviour Onna Daigaku [The Great Learning for Women], published in I7I6, we find a similar statement:

A woman must be ever on the alert, and keep a strict watch over her own conduct. In the morning she must rise early, and at night go late to rest. Instead of sleeping in the middle of the day, she must be intent on the duties of her household, and must not weary of weaving, sewing, and spinning. ${ }^{2 \mathrm{I}}$

As this manual was addressed primarily to upper-class women, it shows that this kind of work was seen as suitable for women of all classes.

Saitō argues that in the course of Japan's proto-industrialization, this traditional division of labour in the peasant family was maintained even when textile production grew and turned into a cottage industry producing for a market, which had to meet a rapidly increasing demand on a national scale. Although there obviously existed a regional division in the workflow between areas growing and ginning cotton and those processing it by reeling, spinning, and weaving, the latter tasks were nearly always taken up by wives and daughters of peasant households who worked at home. This holds true at least for the seventeenth and eighteenth centuries, as a document from I 803 shows, which states "as for byemployments, the men cut firewood and fodder; the women spin and weave cotton yarns for use by the family and for sale if any is left over". ${ }^{22}$

Rare exceptions to this pattern of labour division were the highly professionalized traditional silk weavers of Nishijin in Kyōto, who were mostly male. Their work was apparently seen as a craft and therefore treated differently from the production of home-made cotton thread and cloth. When silk spinning and weaving spread to rural areas, its situation became similar to that of cotton production.

20. Based on the English translation by Ooms, Tokugawa Village Practice, pp. 363-373, 368 . The edict is commonly known as the Keian Edict, as it was issued in the second year of the Keian era. In the I990s its authenticity began to be disputed by some scholars. In his short introduction to the translation Ooms briefly refers to the debate concerning the authenticity of this edict.

2I. The treatise is attributed to the Confucian scholar Kaibara Ekiken (1630-1714). The English translation is by John Murray, Women and Wisdom of Japan (London, 1909), p. 40.

22. Cited in Smith, Agrarian Origins of Modern Japan, p. 78. 


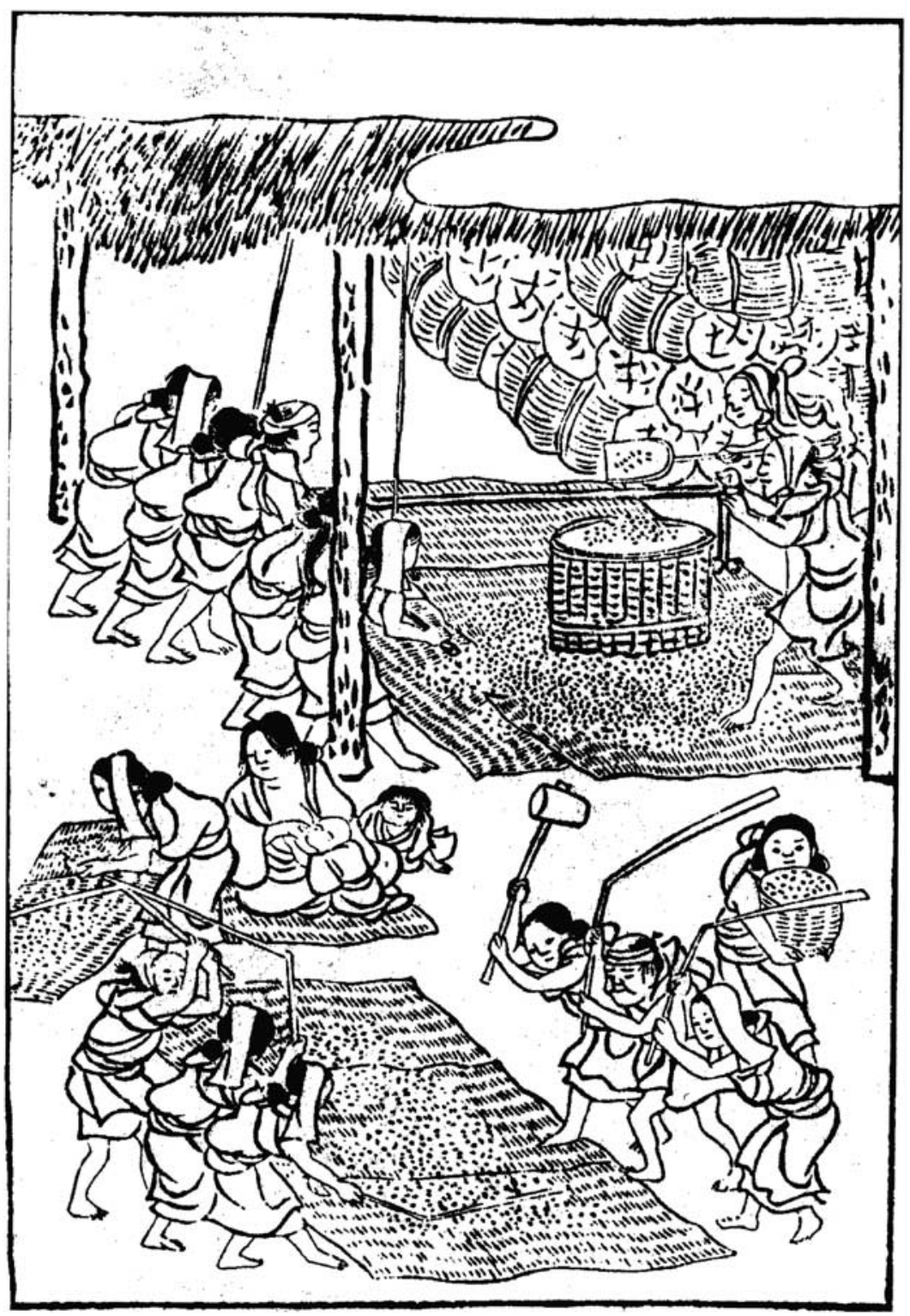

Figure 2. Threshing and husking rice. The picture from the Nogyo zensho shows men and women working together in threshing rice (below) and husking it (above). Men's kimonos are shorter and they wear a towel twisted into a headband, while women wear a sort of headscarf. The woman in the middle is breastfeeding an older child.

Miyazaki Yasusada (Antei), Nōgyō zensho [The Farmer's Compendium] (I696), reprinted in Yamada Tatsuo et al. (eds), Nihon nōgyō zenshū, XII, Nōgyō zensho, Books I-S (Tokyo, I978), p. 42. 
Men usually worked in the fields, and if they took up side work it was mostly in crafts, transport, or petty trade. Based on figures from the nineteenth century, Saito remarks that in areas with rural industries the proportion of men with side work (dual occupations) was generally lower than that of women. ${ }^{23}$ This suggests the important role of women's contribution to Japan's rural industries, especially in the field of textiles.

This view is not undisputed. While some authors, including Murakami Nobuhiko, a writer and author of studies on women's history, emphasizing the subordinate position of women in the hierarchical "house system" (ie-seido) at that time, deny the possibility of men and women cooperating in productive labour, and declare that the contribution of female labour was negligible, others, such as the Marxist historian Inoue Kiyoshi, regard peasant women of the Tokugawa period as relatively powerful and claim they were engaged in productive work cooperatively with male family members. ${ }^{24}$ Yet even though the rise of rural industry largely occurred through the expansion of by-production in peasant households without changing the existing social structures and thus the subordinate position of women in the family and in society, the rapid spread of these rural cottage industries shows that through their by-production the material contribution of women must have been very substantial.

Spinning and weaving were not the only female tasks. Unlike women in northern China, who were strongly discouraged from working in the fields, Japanese women also worked on the land. Except for some women from wealthy peasant families, women from peasant households usually took part in agricultural work, especially in the busy seasons of planting and harvesting. This is evident from several agricultural treatises (nosho), which were published in growing numbers from the end of the seventeenth century onward. Based on Chinese models or on information collected in Japan, and sometimes even on personal work experience, the authors describe various aspects of agricultural activities in writing and in pictures, often with the intention of advancing commercialized farming.

For example, illustrations in the Nogyō zensho [The Farmer's Companion] from the second half of the seventeenth century show women participating in rice planting, weeding, or threshing, in the latter case working side by side with men (Figure 2). ${ }^{25}$ Planting the rice seedlings in the main field was obviously a typical, though not exclusive, job for women. An agricultural

23. Saitō, "Population and Peasant Family Economy", pp. 40-4I.

24. A short outline of this dispute can be found in Wakita Haruko and Suzanne Gay, "Marriage and Property in Premodern Japan from the Perspective of Women's History", Journal of Japanese Studies, 1o (1984)), pp. 73-99, 96-97.

25. Drawings in Miyazaki Yasusada (Antei), Nögyō zensho [The Farmer's Compendium] (1696), repr. in Yamada Tatsuo et al. (eds), Nihon nōsho zenshū, XII, Nögyō zensho, Books I-s (Tokyo, I978), pp. 38-39, 4I-42. 

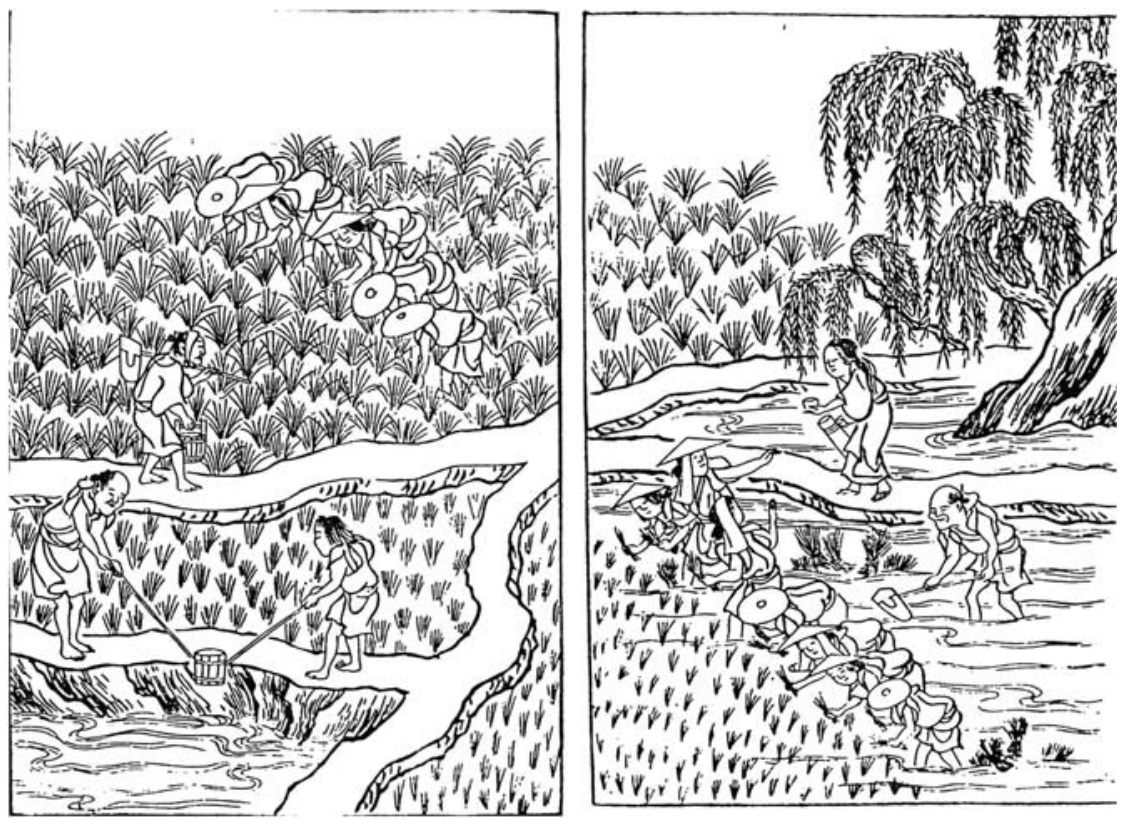

Figure 3. Planting and weeding rice. Saotome (rice-planting women) are planting the seedlings (right), while a man with a hoe is standing behind them. Another woman offers tea or water (left). While men are drawing water, women are weeding the field. Another man with a hoe is passing by. Miyazaki Yasusada (Antei), Nōgyō zensho [The Farmer's Compendium] (I696), reprinted in Yamada Tatsuo et al. (eds), Nihon nōgyō zenshū, XII, Nōgyō zensho, Books I to s (Tokyo, 1978), pp. 38-39.

treatise from 1707 , the Koka shunjū [Cultivating the Soil from Spring to Autumn], gives detailed instructions on how many saotome (rice-planting women) one needed to work a field of a certain size. ${ }^{26}$ The appearance of the obviously young, good-looking saotome in the fields each May seems to have attracted great attention and is mentioned in several verses in the Aizu uta nosho [Agricultural Treatise from the Aizu Region in Verses] (Figure 3). ${ }^{27}$

In the course of the eighteenth century, the demarcation between men's and women's work apparently became more and more blurred. While the

26. Tsuchiya Matasaburō, Kōka shunjū [Cultivating the Soil from Spring to Autumn] (1707), repr. in Yamada Tatsuo et al. (eds), Nihon nōsho zenshī, IV (Tokyo, I980), pp. I7-I8.

27. Sase Yojiuemon, Aizu uta nosso [Agricultural Treatise from the Aizu Region in Verses] (1704), repr. in Yamada Tatsuo et al. (eds), Nihon nōsho zenshū, XX, Aizu uta nōsho, Makunouchi nogyo-ki (Tokyo, I982), pp. 74-75. The author (1630-171 I) came from a wealthy family of village headmen and knew peasant life and agricultural work from his own practical experience - like many of the Japanese writers of agricultural treatises. So we can assume that, even though he was influenced by Chinese writings on agriculture, his writings reflect the reality in eastern Japan. 
hoe is depicted as a typically male tool in the illustrations of the Nogyo zensho, the Aizu fūzoku chō [Record of Customs from the Aizu Region], written 100 years later, mentions that " $[\mathrm{w}]$ ithin the last thirty years women gradually have taken hoes and dug in the fields [...], doing the same agricultural work as men [...] and a really strong woman can work harder than a man". There are similar stories in another source, the Ryūryu shinku-roku [Record of the Hard Work of Peasants] from i 805, about women in the mountains of Echigo province (now Niigata prefecture). They are said to have worked together with their husbands, using axes, forester's hatchets, and sickles, leading a horse or an ox and hauling heavy burdens, and "being not inferior to men [in their work]".

The apparent praise of strong women doing hard work like men in both examples might have contained a slightly critical undertone though: in the same text in the Aizu füzoku cho the author deplores the disappearance of the beautifully dressed saotome of earlier times, who had given way to women working in the fields, unkempt and dressed like men, "so that sexes could no longer be told apart". ${ }^{28}$ It is interesting to note that in these sources, aesthetic criteria are used to convey the impression of certain kinds of work in the fields as being appropriate for women, whereas others where women obviously cross the border into the realm of men's work lead to the loss of their womanliness.

Besides agriculture, women worked in a large number of jobs. In areas where mining was flourishing, women - usually the wives and daughters of the miners - worked in the mines above ground as sluice operators (nekonagashi) and hand pickers (ishidori) (Figure 4), as numerous examples in picture scrolls on mining illustrate. In urban centres women also worked outside the home.

It seems that certain ideas concerning the virtuousness of women and chastity, originating in China, which emphasized that women should stay at home, not work alongside their male relatives in the fields or outside the home, and not remarry after the death of their husbands, were known in Japan, but they had little influence among the lower classes of the rural and urban population. ${ }^{29}$ In the seventeenth century the division of labour in peasant household chores and field work seems to have been even more pronounced than in later years, when women expanded their activities and joined men in their tasks.

28. Aizu fūzoku chō [Record of Customs from the Aizu Region, I807] and Ryūryū shinkuroku [Record of the Hard Work of Peasants, I 805], both cited by Sugano Noriko, "Nōson josei no rōdō to seikatsu" [Work and Daily Life of Peasant Women], in Joseishi Sōgō Kenkyūkai (ed.), Nihon joseishi, III, Kinsei (Tokyo, 1982), pp. 63-94, 92-94; part of the English translation of the citations is based on Anne Walthall, "The Life Cycle of Farm Women", in Gail Bernstein (ed.), Recreating Japanese Women, I600-1945 (Berkeley, CA, 1991), pp. 42-70, 57.

29. Walthall, "Life Cycle of Farm Women", p. 57. 


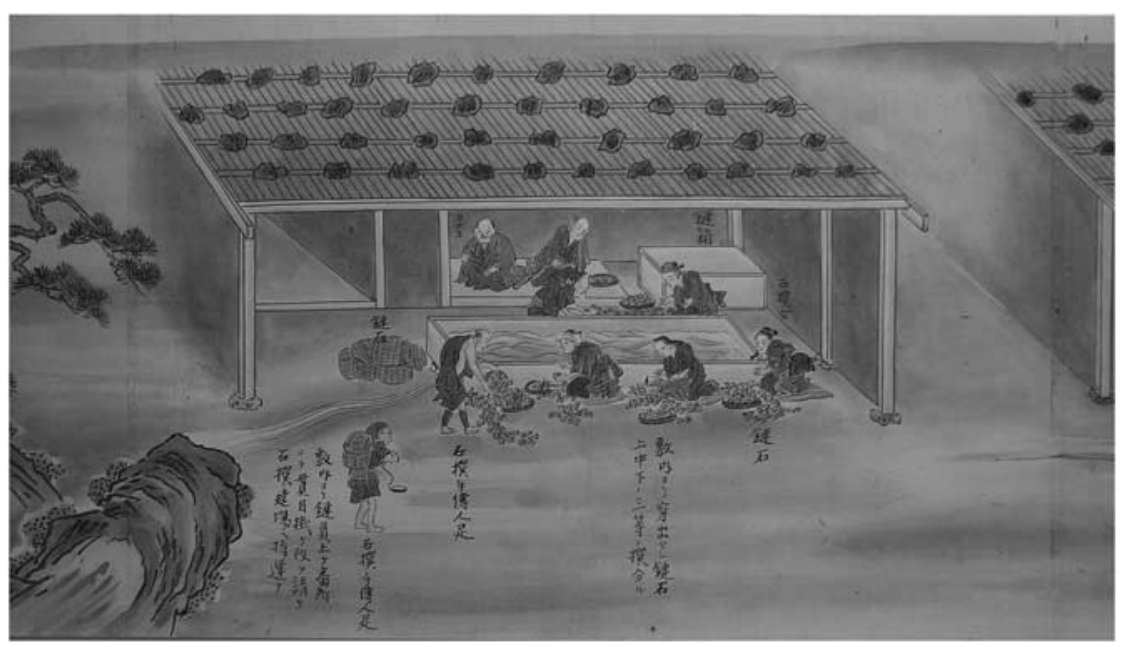

Figure 4. Women working in the mines. Women were employed in mines for many tasks relating to processing the ore, which was mined by men. This picture (from a picture scroll on mining) shows women dividing the ore into three categories by washing it and probing it with a hammer. Picture scroll, Kingin saisei zenzu [On the Mining of Gold and Silver in Sado]. Property of the University of Freiberg, Germany. Used with permission.

\section{THE SITUATION IN URBAN AREAS}

The Japan of the Tokugawa period was one of the most urbanized regions of the world. More than twenty major castle towns, including Edo and Osaka, were established or expanded in the three decades between i 580 and I6ro. They quickly grew, and it is estimated that at the end of the seventeenth century 8 to 9 per cent of the population lived in cities and towns with more than 30,000 people, and in some cases with several hundreds of thousands of inhabitants. ${ }^{30}$ If smaller market towns of 3,000 inhabitants are included, the share of the urban population rises to I6 or 17 per cent. The urban growth was led by Edo, the population of which increased from about 100,000 in 1610 to roughly 400,000 in the 1640 , to as many as 800,000 in the 1680 , and to over $1,000,000$ inhabitants by the $1720 s .{ }^{31}$ In the large cities, new patterns of consumption and new modes of social organization and labour relations evolved, and gradually spread to smaller towns.

30. John Whitney Hall, “The Castle Town and Japan's Modern Urbanization”, The Far Eastern Quarterly, I5 (1955), pp. 37-56, 44, 51. Around I700 about io per cent of the population lived in cities of over 10,000 inhabitants.

31. Gilbert Rozman, “Edo’s Importance in the Changing Tokugawa Society”, Journal of Japanese Studies, I (1974), pp. 91-I I 2, 93, n. 7 . 
The traditional labour force of the sixteenth century in non-agricultural occupations consisted mostly of three groups: conscripted peasants, artisans, and hereditary domestic servants in samurai households. For larger projects, such as the construction of houses, castles, or roads, the feudal lords and their local retainers relied on corvée labour by the peasantry. Ever since the first legal code of the eighth century, corvée labour (buyaku) had been a kind of tax to be paid by the peasants.

The second group were the artisans (shokunin). While the term in the thirteenth and fourteenth centuries obviously described all kinds of skilled people working outside agriculture, artisans in the narrow sense of this term (shukogyosha, literally "handworker") emerged during the fifteenth and sixteenth centuries. The social status of these artisans was characterized by a tendency towards increasing freedom to travel and to enter employment. However, the degree of this individual freedom is still disputed among scholars. ${ }^{32}$ The range of occupations was already quite differentiated, and they were obviously paid for their work, though in kind (as unhulled rice). There were artisan organizations, mostly small local guilds (za, kabu-nakama) in the early sixteenth century, but they were dissolved in the process of unifying the country, because they were often seen as an obstacle to trade expansion. In the Tokugawa period, exclusive trade organizations (nakama, kabu-nakama) and artisan groups resurfaced in the cities.

The third group were servants. There were many terms for these, including fudai (hereditary), like the servants in the countryside, or bikan (in this context meaning servant of an urban family), and they were distinct from slaves. They could, for example, get married as they wished, but they and their descendants were considered members of their master's household and were not free to leave their employer. ${ }^{33}$ If a family was split up, the girls would follow the mother and the boys the father. Jansen described the fudai in the samurai households in the fief of Tosa (Shikoku) as semi-free indentured servants. ${ }^{34}$ There are few documents on servants in commoner households in the late sixteenth and early seventeenth century, but they also seem to have been fudai or in a similar position, and there is no evidence of a different form of non-hereditary, short-term service at that time. ${ }^{35}$

32. A thorough analysis of the term shokunin and its historical interpretations can be found in Klaus Vollmer, Professionen und ibre "Wege" im mittelalterlichen Japan. Eine Einführung in ibre Sozialgeschichte und literarische Repräsentation am Beispiel des Töhoku'in shokunin utaawase (Hamburg, 1995), passim, and pp. 101-102.

33. Leupp, Servants, Shophands and Laborers, p. I3.

34. Marius B. Jansen, "Tosa in the Seventeenth Century: The Establishment of Yamauchi Rule", in John W. Hall and Marius B. Jansen (eds), Studies in the Institutional History of Early Modern Japan (Princeton, NJ, I968), pp. I I 5-130, I06, I 21.

35. Leupp, Servants, Shophands and Laborers, p. I s. 


\section{THE INTRODUCTION OF LABOUR CONTRACTS}

The seventeenth century saw a major transformation in the organization and the character of service and labour. Initially, traditional forms of work still prevailed. A hundred years later several authors deplored the disappearance of lifetime servants and corvée labourers. These changes started in the early half of the century, but gathered momentum after I 650 and, according to Mary Louise Nagata, provided a coherent framework of labour relations that lasted for 200 years. ${ }^{36}$

In her comprehensive study of the development of labour contracts concerning service in merchant, artisan, and manufacturers' households, Nagata has traced the beginnings of such contracts to the seventeenth century, although they became common only a century later. According to her findings, summarized below, during the seventeenth century the repeated bans by the Tokugawa shogunate on selling people into service made it necessary for those engaged in craft, trade, and industries to look for other forms of employment. At the same time many businesses went through a period of rapid expansion, creating a demand for labour that could not be satisfied by employing only kin, children of friends, or other people well known to the employer. To secure a disciplined and stable labour force, employers started to use contracts, which in the late seventeenth century still tended to be verbal, but which were soon replaced by written contracts.

These contracts served first and foremost as "letters of guarantee", signed by a guarantor, who knew the applicant and took responsibility for his or her good conduct. Such contracts soon became standardized, and typical clauses would include: the relationship between guarantor and employee; hints concerning the religion of the employee to indicate that he was not a Christian and was registered at a certain temple; a pledge that the employee would obey the laws and rules of the employer's household; and the contract provisions and responsibilities of the guarantor. The involvement of such a guarantor had been required by the central government as early as I665 in the face of widespread abuse, such as running away and not fulfilling contracts, and instability. Laws in the years I666 to I668 sharpened the regulations, indicating that the employers' worries and the government's efforts to retain (or gain) control over the new forms of employment had not yet been successful. ${ }^{37}$ Nagata points out, that "[a]t the end of the seventeenth century wage labor was common and written contracts identifying one or more guarantors were the main mechanism for controlling abuses of the system" ${ }^{38}$ 
Service in merchant or artisan households was usually based on longterm contracts. Servants, male and female, lived on site, being provided with a bed, board, clothing, and other necessities by the employer. When these households started to hire more short-term labour for unskilled or semi-skilled tasks, two different modes of employment evolved during the eighteenth century: long-term contracts - often for periods of ten years were used for apprentices, skilled labour, and management employees, while domestic servants often had short contracts ranging from six months to one year. ${ }^{39}$

As early as I6 10 a "servant replacement day" (dekawari-bi) on which servants could be dismissed or hired was designated in Kyōto, and Edo introduced this custom three years later. During the seventeenth century the system became common in most cities and even in villages. During the Genroku period (I680-1704) a second replacement day was added, making it possible to hire and fire servants, and from the perspective of servants to leave their employer, every six months. Dazai Shundai (I680-I747), a Confucian scholar, complained in his writings about these new developments, which loosened the bond between master and servant. He wrote: "In China there is no class similar to that of the house servants of these times, who are called dekawari servants [...]. They change their masters each year and therefore their employers do not show them much kindness, and the employees show very little fidelity to their masters." 40

Changes occurred too in the payment of wages. According to Nagata's findings,

In the late seventeenth century wages for labour contracts still tended to be paid in advance to the employee's family, making wage labour an indentured relationship. By the early eighteenth century contracts began to specify that the wage would be paid directly to the employee either at the end of the contract or at periodic intervals during the contract. ${ }^{4}$

We can conclude therefore that, starting around the mid-seventeenth century, servants, who until then had been limited mostly to samurai households, became a widespread phenomenon in commoners' households and businesses in urban areas. This process was accompanied by significant changes, such as the emergence of written contracts, the transition from indentured service to wage labour, the increase in short-term employment, and wage standardization. At the same time, labour relations in services requiring intensive training and special skills tended to retain many features of the traditional long-term paternalistic employment system.

39. Ibid., pp. I6-17.

40. Leupp, Servants, Shophands and Laborers, pp. 22-24.

4I. Nagata, Labor Contracts and Labor Relations, p. I6. 


\section{THE DEVELOPMENT OF FREE AND CASUAL LABOUR}

As mentioned before, the decades around the turn of the sixteenth century were a period of unprecedented urban growth. The Tokugawa regime and the feudal lords invested in infrastructure by building roads and waterworks, organized transport, and operated mines. Wakita Osamu suggests that for certain construction projects, such as Ösaka Castle, the regime at times mobilized I0,000 workers per day. That figure was presumably the number of man-days and included construction workers, workers in quarries, lumberjacks, transport workers, and various kinds of artisans. ${ }^{4^{2}}$ The simultaneous realization of many large-scale and even more small-scale projects must have created an enormous demand for labour, which could have never been met solely by peasant corvée labour, without seriously endangering agricultural production - and thereby also the tax income of the feudal elite, because taxes were paid in kind, mostly in rice.

In his detailed and comprehensive study on the rise of urban labour in Tokugawa Japan, Leupp concludes that from the mid-1630s a new type of hired casual labourer came to replace corvée workers in castle-town construction projects. While in the I 580 s and I 590 S Toyotomi Hideyoshi had still explicitly forbidden the hiring of day labourers, the attitude of the central administration changed during the following decades.

In I636 a supervisor of construction works at Ōsaka Castle, the territorial lord of Higo, Hosokawa Tadatoshi, wrote a memorandum to the shōgun, stressing that it would be preferable to hire wage labourers rather than use corvée labour; the latter should better concentrate on rice production. ${ }^{43} \mathrm{In}$ I653, an edict was issued in Edo stating "As it was formerly commanded, people working as day-laborers must receive a license $(f u d a)$ from the daylaborers' chiefs (biyatoi-gashira). Anyone employing persons without such a license will be fined. This is a criminal offense." ${ }^{44}$ This is said to be the first surviving edict mentioning day labourers in this context. Four years later a similar edict was issued in Ōsaka. Both edicts seem to indicate that around the middle of the century the shogunate had given up its general rejection of hired labour, and was trying instead to cope with the new kind of labour force by introducing new methods of control.

Most of these casual labourers came from impoverished rural areas and had flocked to the cities and towns in their thousands, searching for work and a way to make a living. According to Rozman, Edo's population may

42. Wakita Osamu, "Kinsei shoki no toshi keizai" [Urban Economy in the Early Years of the Early Modern Period], Nihonshi kenkyū, 200 (1979), pp. 52-75, 63. These figures are based on estimates by Wakita, who calculated the number of labourers by taking the overall costs of labour and dividing them by average wages. According to this, there would have been several millions of people (or possibly man-days) per year.

43. Leupp, Servants, Shophands and Laborers, p. 17.

44. Ibid., p. I60. 
have grown by 10,000 immigrants a year during the first half of the seventeenth century, and by i 5,000 immigrants a year during the second half. ${ }^{45}$ The casual labourers were employed on a daily, ten-day, twentyday, or monthly basis. As the free movement of people was still forbidden and peasants were not supposed to leave their land, the government at first repeatedly rounded up these rural immigrants in the cities, especially in Edo, and returned them to their native villages. Around the middle of the seventeenth century, as the above-mentioned edict shows, the shogunate seems to have changed its policy and started to recognize casual labour as part of economic and social development. Around I700 onefifth to one-third of the urban population in Japan consisted of hired servants, shop hands, and manual labourers. ${ }^{46}$

A closer look at the composition of this labour force shows that it comprised both men and women. Although women were fewer in number than men, they performed many jobs in the cities, such as shop hands, tailors, laundresses, dyers, pedlars, and hawkers. ${ }^{47}$ Leupp mentions one example of thirty-two day labourers in the castle town of Kasama (Hitachi province, now Ibaragi prefecture) in 1705 , among them six women, who were all widows. Other examples also suggest that women often had to work to make a living or at least supplement their insufficient household income. For them, the growing diversity of jobs in the cities offered alternatives to the traditional resort in times of economic need, namely prostitution.

A rare example of female artisans is given in one of the writings by Ihara Saikaku (1642-1693), who mentions female carpenters who worked at the women's quarters in the Imperial Palace in Kyōto and "do this for a living" ${ }^{8}$

The age of day labourers varied greatly. Some labourers seem to have begun working at the age of fourteen or fifteen but, as Leupp points out, in several documents the recorded average age of day labourers is surprisingly high, sometimes even exceeding fifty years. ${ }^{49}$

In contrast to most of the corvée labourers, who were provided only with room and board, the newly emerging group of casual labourers were obviously paid wages. Conservative intellectuals noted and often deplored this change. In 1730 the Confucian scholar Ogyū Sorai (I666-I728) wrote: "Until seventy or eighty years ago the employment of day-laborers was unheard of". Around the same time, his contemporary Dazai Shundai noted that:

It is rare nowadays to use peasants as corvée labor. For such [tasks] as public work, workers in the capital are hired for wages [...]. Nowadays lords do not employ people of their provinces, but hire them for wages in Edo. Wage-work

45. Rozman, Edo's Importance, p. Ioo.

46. Leupp, Servants, Shophands and Laborers, p. 176.

47. Ibid., p. I39.

48. Cited in ibid., p. 138.

49. Ibid., p. I39. 
(chinpu) is, by the current custom, referred to as day labor (biyo). For virtually every type of work, people are hired for money. So people do not suffer, but on the contrary, they prosper. This is different from the old practice. ${ }^{5 \circ}$

So, at the end of the seventeenth century wage labour was widespread in urban areas, and even in Dazai Shundai's statement this is depicted as a positive trend.

One question is whether wages were paid directly to the individual worker. A regulation dating from 1657 that tried to limit the wages to be paid to different groups of day labourers gave the respective amounts in "one unit of gold $(r y o)$ per 45,65 or 70 persons", depending among other things on whether they owned their tools or not. This seems to indicate that the whole sum was often given to some kind of labour boss, who would then in turn hand part of it to the workers he was in charge of, and keep the rest to pay for his expenses and a profit. ${ }^{\text {I }}$

Wage levels seem to have fluctuated widely depending on demand and supply, and the authorities repeatedly (though mostly unsuccessfully) tried to keep them down. The new economic developments, the emergence of wage labour, the rise and fall in prices and wages, and the growing impact of money on the economy were important topics in scholarly debates in Japan from the late seventeenth century onward. In the early phase, neo-Confucian scholars, including Arai Hakuseki (I657-1725) as well as Ogyū Sorai and Dazai Shundai, dominated the debate. They mostly deplored the new developments.

In contrast, the economist and philosopher Miura Baien (1723-1789), a contemporary of Adam Smith, although very critical about the money economy and the accumulation of wealth in the cities, did not plead for the complete abolition of money and wage labour. Instead he wrote a chapter on "the price of wage labour", in which he thoroughly analysed the connections between the situation in rural areas and wage labour in the cities. In his eyes, the shift of large numbers of poor peasants between agricultural work in years of abundance and wage labour in the cities in years of bad harvests was the main reason for wage instability. So he recommended improving the economic situation of small peasants to keep them on the land and separate them from urban wage labourers. ${ }^{52}$ In his writings he acknowledges the existence of wage labour as an irrevocable fact, proving the consolidation of the new

50. Citations based on ibid., pp. I6-17.

51. Ibid., p. I6r.

52. Based on the complete German translation of Miura's work Kagen; Miura Baien, Kagen. Vom Ursprung des Wertes. Faksimile der zwischen 1773 und 1789 entstandenen Handschrift (Düsseldorf, 200I), Günther Distelrath et al. (eds), Kagen. Vademecum zu einem japanischen Klassiker des ökonomischen Denkens. Kommentarband (including the complete German translation of Kagen) (Düsseldorf, 200I). Here I refer to the chapter "Der Preis der Lohnarbeit" in Kommentarband, pp. I87-191. 
economic trends, but he advocated measures to reach a balance between rural and urban developments, rather than leaving them to market forces.

The emergence of new forms of urban labour with short-term contracts and a comparatively free labour force, along with increasing migration to the cities leading to a growing number of urban poor, alarmed the authorities. They reacted by setting up new measures and mechanisms of control.

One measure was to round up peasants and other people from the countryside in the cities and order them to return to their villages. This policy, called hitogaeshi (to return people), was sporadically applied throughout the Tokugawa period, but intensified in the late $1780 \mathrm{~s}$ and the I 840 s, when famine drove large numbers of peasants from the countryside into the cities. Repeated edicts by the central administration (bitogaeshi-rei), however, suggest that this policy did not succeed, probably due to the deteriorating situation in many villages, the sheer numbers of immigrants, and the lack of sanctions. These and other measures, and their consequences, show that the authorities could not and would not prevent the spread of wage labour in the cities and towns, even though this was clearly undermining the ideological basis of the political, social, and economic system. Nevertheless, the emerging labour market around I650 had clear limits. The individual labourer may have been free in comparison with part of rural society, but this freedom was strictly regulated and became even more so in the course of the eighteenth century when administrative policies seem to have become more effective.

\section{WORKERS'ATTITUDES TOWARDS WORK}

After this exploration of both government policies towards work and mobility at the central and local levels and the opinions of scholars and thinkers, the question of the workers' own attitudes and self-image needs to be addressed. Moral indoctrination provided another option for control.

Contemporary sources give us little information about the moral ideas or the work ethic of servants and labourers. The spread of neo-Confucian ideas in the seventeenth century led to moral rules and prescriptions of correct behaviour for the "four status groups" (warrior, peasant, artisan, merchant), which became firmly entrenched in society after the turn of the century but whose origins can be traced to the reforms of Toyotomi Hideyoshi in the I 580 . The underlying theoretical construct, based on an ancient Chinese model, combined legal conceptions and a moral hierarchy with a social division of labour. ${ }^{53}$ The interrelation of occupation and

53. In Japan the four status groups (shimin, also translated as four classes, four peoples, four orders, and in German Vier-Stände-System) were often reduced to three by merging the last two groups, artisans and merchants, into one, and labelling them "town dwellers" (chönin). A comprehensive outline of questions related to the historiographical treatment of status, class, 
morality resulting from this concept constituted the framework in which scholars in the Tokugawa period reflected upon work and social status.

In his study on the perception of work in Tokugawa Japan, Takemura Eiji shows that the terms used for work (sugiwai, nariwai) in a JapanesePortuguese dictionary from 1603 implied a productive activity to gain the means of one's living. But other terms, such as shokubun or tenshoku, referred to "one's occupation or trade (shoku), fulfilling an allotted part (bun) in society". According to this neo-Confucian ideology, all status-related occupational groups were expected to "be diligent in fulfilling one's own shokubun". So the concept of work was strongly related to one's role and status in society. ${ }^{54}$ As Takemura relies, among other sources, on one of the supplements written by Kaibara Rakuken (1625-1702) to the above-mentioned Nogyo zensho, published in I696, we can assume that this concept of shokubun was already part of the practical literature for peasants in the late seventeenth century.

One of the most influential schools in the dissemination of such a work ethic for the three lower-status groups was the Shingaku [The School of the Heart] by Ishida Baigan (I685-1744). Under the leadership of Ishida Baigan and his successors, the teachings of Shingaku spread from Kyōto and Ösaka to other parts of the country during the second half of the eighteenth and the early nineteenth centuries. At its height there were more than 170 centres and Shingaku academies in various parts of the country, many of them in towns that were not castle towns, and in rural areas. So Ishida Baigan's ideas were disseminated among all status groups during the decades after his death. 55

He propagated the pursuit of self-cultivation among all status groups, not only the elites, while at the same time linking it to practical action, namely the devotion to one's work and the acquisition of skills. He saw the shokubun as an assignment by Heaven and argued that "samurai are samurai, peasants are peasants, and merchants are merchants. [...] if one is loyal to Heaven's assignment, and is devoted to it, one shall certainly reach the state of fulfillment". ${ }^{66}$ While adhering to status distinctions, Ishida Baigan apparently demanded respect for all who fulfilled their role in society. In one of his writings, "Tohi mondō" [A Dialogue between Town and Country] from I739, a merchant's apprentice speaks with contempt about day labourers, to which Ishida Baigan replies: "How do we differ from day laborers? It is

and the social division of work is provided by Douglas R. Howland, "Samurai Status, Class, and Bureaucracy: A Historiographical Essay”, Journal of Asian Studies, 60 (2001), pp. 353-380, $353-367$.

54. Takemura Eiji, The Perception of Work in Tokugawa Japan: A Study of Ishida Baigan and Ninomiya Sontoku (Lanham, MD, 1997), pp. 24-27.

55. Ibid., pp. 94-96.

56. Ibid., pp. 55-56. English translation by Takemura Eiji. 
narrow-minded to regard day laborers as lowly". Other examples stressing that artisans and other workmen are as important to society as samurai, peasants, and merchants also prove that there was no general disdain of physical labour displayed in the writings of the intellectual elite. ${ }^{57}$

The question remains how and to what degree Confucian values and ideas about hard work, diligence, and fulfilling one's role in society were internalized by the lower classes of society. They must have been exposed to and influenced by contemporary ideas about morals and appropriate behaviour.

First, in the first half of the seventeenth century, most of them came from rural areas. In the above-mentioned edict of $\mathrm{i} 649$, peasants were admonished to rise early and go to sleep late, work with the greatest diligence, and not waste time and resources. Advice books such as the Nogyo zensho contained not only practical advice but also moral ideas. Second, those who worked for longer periods in merchant houses or artisan workshops would have been exposed to similar ideas there. Third, such ideas could have been circulated by those members of the merchant or artisan status groups who controlled the labourers, such as the hiyatoi-gashira (merchants), officials of the registry, or even landlords. Last but not least, the poor houses or workhouses may also have served this purpose.

That they were not necessarily just punitive institutions but regarded by some authorities as an example of benevolent government and assigned an educational task is conveyed in the statement of a senior councillor in I778, which expresses hope that "immoral and dissipated vagrants" committed to the workhouses at the Sado mines could be "rehabilitated", and after "mending their ways" return to society. ${ }^{58}$ Work was obviously used as an instrument to discipline those who were seen as a threat to the social order of Edo and other cities, but potentially also as an instrument for improvement. These examples concern vagrants, but the lines of demarcation between vagrants and day labourers were blurred, and many of the "vagrants" might have been unlicensed casual labourers.

A final interesting point, mentioned by Leupp, is the fact that, at least as late as the early nineteenth century, inmates of the Edo yoseba (large workhouse) were exposed three times a month to a kind of rehabilitation programme, in which they had to attend lectures given by scholars of the Shingaku school, a moral doctrine amalgamating Confucian, Shinto and Buddhist elements with a strong work ethic, predominant in the merchant class. ${ }^{59}$ This example is too late to use as evidence for the situation in I650. It marks, however, the end of a development during which ideological concepts of work were spread among the status groups. It is doubtful that workers around I650 had already internalized such ideas,

57. Leupp, Servants, Shophands and Laborers, pp. I 50-I I I, I 26.

58. Tanaka Keiichi, Sado Kinzan [Sado Gold Mines] (Tokyo, 1980), pp. 228-229.

59. Leupp, Servants, Shophands and Laborers, p. 174. 
but the I649 edict on peasants shows that the indoctrination of society's lower classes had already begun by then.

To what degree these moral ideas shaped their actions and attitudes and how they might have resisted them is hard to say. In popular fiction, especially in the novels of the seventeenth-century writer Ihara Saikaku, as well as in many senryu (short comical verses) and kobanashi (humorous anecdotes), servants are often depicted as lazy, pleasure loving, gossipprone, and unreliable, sometimes clumsy and ignorant, sometimes very shrewd. Hired workers are similarly depicted drinking, gambling, and spending their earnings in the pleasure quarters. ${ }^{60}$

These stereotypes were obviously especially popular with the public, because they contravened the prevailing Confucian values. On the other hand they might also partly reflect the fact that the new kind of shortterm employment might have loosened the bonds with employers and offered these groups opportunities to pursue their own ideas about a good life. They nevertheless hardly reproduced the authentic view of the groups concerned.

Work songs, which could reflect this view, exist, but it is nearly impossible to link them to a certain period of time. Some like rice-planting or weaving songs could probably be traced back to the seventeenth century, while others dealing with coal mining or female workers (joko) can be linked at best to the late eighteenth and early nineteenth century because the work they describe did not exist in earlier times.

If the songs relate directly to the work, the most frequent topic is the hardship endured by workers. In the cotton beaters' song, work is characterized by words such as tsurai (harsh, severe) or kuro (trouble, hardship). ${ }^{61}$ "Sing, sing they kept urging me, but a song wouldn't come out, only sweat", or "If you're suffering at work, instead of crying, sing. If the song is good, you'll cheer up". ${ }^{62}$ In some songs related to peasants' work we find complaints about backs sore from planting rice or the expressions of loneliness by indentured servants, but rarely expressions of social or political protest or antagonism towards one's immediate superiors. ${ }^{63}$ Hughes cites two examples of songs expressing critique. In one, a local entrepreneur is bedevilled by indigo workers: "the tycoon of Awa is a devil from hell; he does not extract indigo dye, he extracts blood". Another one focuses on the relationship between peasant and the local landlord: "the peasant is mouse, the squire is a cat, his eyes on the peasant

6o. Ibid., pp. 108-I I 2, I 5 I.

6I. Machida Kashō et al. (eds), Nihon minyō shū [Collection of Japanese Folk Songs] (Tokyo, I963), pp. 203-204.

62. David W. Hughes, Traditional Folk Song in Modern Japan: Sources, Sentiment and Society (Folkestone, 2008), pp. 73-74.

63. Ibid., p. 56. 
drowsily [thinking I'll catch him]", ${ }^{64}$ but they could be from the eighteenth or nineteenth centuries. Other songs, such as the pottery song from Bizen, praise the master, "The Lord of Bizen is a great and noble man. Thanks to our lord the kiln flourishes. When the kiln flourishes so does the whole village". 65

Indirect information about the work ethic of servants or employees in merchant and artisan households is likely to be found in sources dealing with conflicts between masters and servants. Nagata has pointed out that contracts usually contained provisions against absconding and disappearing after theft. According to her, swindling scams were apparently a problem in the seventeenth and eighteenth centuries, and guarantors were usually held responsible for bringing the fugitives back or compensating the employer for his losses. The few cases she presents in her study seem to indicate that such troubles occurred quite frequently, even with the same person being hired, fired, and re-hired. ${ }^{66}$ So a broader analysis of this kind of source could surely provide us with a better insight into the attitudes of workers and servants towards their work.

\section{CONCLUSION}

So far Japanese economic historians have focused mostly on the eighteenth and early nineteenth centuries as periods in which certain new characteristics of the Tokugawa period, such as urbanism, commercial agriculture, and the growing importance of the money economy, fully developed. The years I 500 and I650, which were fixed as cross sections in the framework of the comparative research project to which this article contributes, have no special meaning in Japanese history. A closer look, however, reveals that I 500 may be seen as symbolizing a period in which the old order of the landed estates was rapidly dissolving, and new forms of labour relations among artisans and other workmen were evolving.

The cross section of 1650 sets the focus on the seventeenth century. It turns out to have been of special importance for the formation of new forms of labour relations, the development of industry in rural areas, the increase in female labour, and for reflection on all these changes. One of the main trends in both urban and rural areas was the development of short-term employment. In the course of the seventeenth century, lifelong service in urban, and partly in rural, households was replaced by forms with a fixed span of years, which by the end of the century could be freely negotiated between employer and employee. For those aspiring to a career of service in the households of merchants and artisans, the form of

64. Ibid., pp. 59-60.

65. Ibid., p. 52.

66. Nagata, Labor Contracts and Labor Relations, pp. IOI-I I 8, passim. 
long-term service was preserved, but as more and more strangers were employed, written contracts became quite common.

At the same time, casual labour remunerated with wages replaced corvée labour in the towns and larger cities. This led to the emergence of an urban stratum of day labourers, workmen, small artisans, and pedlars, who often came from the countryside. The shogunate tried to control the evolving market for this kind of urban labour by strict regulations, but the repeated issue of such regulations shows that its efforts were only partly successful. Finally, even Confucian scholars such as Dazai Shundai and also the shogunate itself had to concede that the new forms of labour also had advantages.

The prevailing ideology of neo-Confucianism was without doubt very influential in shaping the concepts of work and one's role in society based on status and occupation. While it is hard to grasp its direct impact on the daily life of the people, images of indolent servants with loose morals on the one hand and the complaints about exploitation on the other have been passed down to us in literary and historical documents. Reconstructing the work ethic as it was understood and practised by the lower classes of Tokugawa society remains a topic for further research. 